\title{
ASEAN-CHINA RELATIONS AN OUTLOOK ON GEOPOLITICAL AND ECONOMIC STRATEGY ASEAN SHOULD PURSUE IN ITS RELATIONS WITH CHINA
}

\author{
Saamiya Laroia \\ The Shri Ram School, Aravali \\ DOI: 10.46609/IJSSER.2020.v05i09.011 URL: https://doi.org/10.46609/IJSSER.2020.v05i09.011
}

\begin{abstract}
In the first quarter of 2020, ASEAN became China's largest trading partner despite the tense political climate of clashes in the South China Sea and the US-China Trade War. This is an indicator of the deepening economic ties and regional integration of the two bodies; however. to sustain this mutually beneficial relationship ASEAN needs a comprehensive plan to negotiate its role in the Belt and Road initiatives, implement transparent economic policies and further South China Sea negotiations. This report gives an overview of the Belt and Road initiative, economic relations and the South China Sea issue in relation to ASEAN- China relations and recommends strategy ASEAN should pursue in regards to them.
\end{abstract}

Keywords: ASEAN, geopolitical, Economy, Trade, relation

\section{Belt and Road Initiative}

China's Belt and Road initiative is one of the most significant projects of the twenty first century and for South East Asia, it bring enormous opportunities in trade, finance and engineering. One of Asia's most pressing regional concerns are the infrastructure gaps obstructing integration and development. The Belt and Road initiative has been widely regarded as an ideal vehicle to bridge this gap, having received billions in funding and consisting of 138 countries as of March 2020, 6 of which are South-East Asian Nations. (Wang, 2020) The Asian Development Bank (ADB, 2017) has estimated that Asia will need to invest \$1.7 trillion per year in infrastructure until 2030 in order to tackle climate change, eradicate poverty levels and maintain growth momentum, with South-East Asia requiring investment accounting for 5.7\% of GDP. The climate adjusted need estimate for ASEAN countries till 2030 is US\$3.1trillion and it is important to note that a major tent of the BRI is low-carbon, sustainable and high quality infrastructure. While infrastructure investment needs largely exceed current plans under BRI, it is incontrovertibly the most 


\section{International Journal of Social Science and Economic Research}

ISSN: $2455-8834$

Volume:05, Issue:09 "September 2020"

significant contribution to those needs. However, the BRI entails more than just hard infrastructure and through 'connectivity' also influences the dimensions of trade, capital and soft infrastructure.

The ACFTA was the first FTA with external parties to be signed by ASEAN and was upgraded in 2014 as part of the BRI which accelerated trade and investment. Being geographically proximate Singapore, Vietnam, Thailand, Malaysia, Cambodia, and Myanmar all have amongst the top ten most connected trade supply chains to China. (LSE, 2018) And while there is already narrowing of gaps between ASEAN exports to and from China, the BRI could facilitate more efficient narrowing of the trade imbalance. China also has over $\$ 740$ billion in total BRI investment in Southeast Asia with Indonesia (US\$171bn), Vietnam (US\$152bn), Cambodia (US\$104bn), Malaysia (US\$98bn) and Singapore(US\$70bn) seeing the largest BRI related capital flow. (The Diplomat, 2020). These connectivity channels also include soft infrastructure - flows of labor and educational and tourism opportunities can be created through BRI which have key importance in the Asia-Pacific region.

A report by (LSE, 2018) found that "Between 2014 and 2016, ASEAN trade in services with the world has shown an increase in import of services in the sub-sectors related to the BRI projects". It also mentioned that upon the completion of BRI, not only will there be an increase in the export of transportation and travel services, especially in tourism, through the BRI infrastructure projects in ASEAN states, there will also be opportunity to bridge the trade imbalance between ASEAN and China, to overcome problems of inadequate infrastructure and to draw investment into sectors like manufacturing, energy and services. Upon completion of the BRI, ASEAN exports into China and Europe will be facilitated by the Vientiane-Boten Railway, ECRL and Gemas-Johor Bharu, Phongxaly-Yunnan projects in Laos and Malaysia; the BRI's Last Mile road will be able to connect ASEAN to its key global partners, alleviating the needs to rely on the sea route to reach certain parts of China, Central Asia, Russia, and Eastern Europe; the East Coast Rail will connect Port Klang in the Straits of Mallaca, South China Sea Port of Kuantan and Malaysia so vessels will not need to travel through traffic-heavy Singapore Straits. (Jusoh, 2018)

ASEAN has much to gain from the BRI, not only from availing the immense connectivity and material benefits it offers by participating but also by actively offering regional perspectives and legal frameworks. Currently, a number of BRI projected have been adversely impacted by the lack of manpower, an effect of border shutdowns in response to COVID-19. In conjunction with the solidarity shown in the China-ASEAN and Beijing's recent proclamations of 'interdependence' ASEAN could negotiate for hire of local manpower at BRI sites. (The Diplomat, 2020) Interdependence and multilateralism are key to the success of BRI; it is crucial 


\section{International Journal of Social Science and Economic Research}

ISSN: $2455-8834$

Volume:05, Issue:09 "September 2020"

for it the project to engage more participants as meaningful stakeholders. ASEAN has the leverage to effectively engage and negotiate with China over this project as the regional body enjoys centrality in Beijing's diplomacy after the pandemic caused growing skepticism and deterioration of Sino-European relations. (European Council on Foreign Relations, 2020)

If ASEAN manages to pull its weight as a stakeholder, it will prove that the BRI can shift towards a multilateral approach where more resources, expertise and perspectives can be pooled. This would dispel many of the concerns about the project and ensure better results in the long term.

If ASEAN participates in not only receiving but also giving to the BRI, it can bolster both political and material gain for itself. By ASEAN asserting itself and responding to Beijing's claims of BRI being a global, multilateral "win-win" project by creating deals for itself, it can advocate for sustainable, equitable deals by acting as a counterweight against China.

As a precedent, China itself has been increasing its involvement in the World Bank's administration and contribution to the bank since joining in 1980. As its economic power grew, it overtook large European nations in voting power in 2010, which increased from $2.77 \%$ to $4.42 \%$. (Reuters, 2010). ASEAN can similarly push for more involvement and administrative power in the project. Interdependence is the key to success of the BRI and the more nations involved that act as a counterweight to China, the more everyone involved can benefit.

ASEAN has the potential to not only be an economic partner to China but to be an active participant of Beijing's much-touted vision of multilateralism with regards to the Belt and Road initiative. It could address the current risks of participation in the BRI by persuading China to broaden multilateralism and participation so as to leverage on ASEAN's potential engagement. China has shown willingness to accommodate negotiation and allow for more equitable deals; Malaysia successfully renegotiated East Coast Rail Link and not only lowered the price from $\$ 23.2$ million per kilometer to $\$ 16.7$ million per kilometer but increased the percent of construction jobs for workers from $30 \%$ to $40 \%$. (Benar News, 2019) The project is expected to benefit shipping and logistical industries and boost industry growth in the region. Another indicator is that in 2019, China and Singapore agreed to assemble a panel of international mediators to resolve disputes regarding Belt and Road. China and Singapore plan to mutually develop rules, management protocols, and enforcement procedures (Chang Law, 2019) Singapore stands to become a crucial player in the BRI due to its financial connectivity with $60 \%$ of project finance transactions across ASEAN being led by Singapore-based banks. and it being a potential third-country partnership hub.

By multilateralising BRI, ASEAN nations can play central supporting roles in negotiation, mediation, financial connectivity and third part collaboration as well as reap the benefits of a project that if completed could reduce travel times along economic corridors by $12 \%$, increase trade between $2.7 \%$ and $9.7 \%$, increase income by up to $3.4 \%$ and lift 7.6 million people from 


\section{International Journal of Social Science and Economic Research}

ISSN: 2455-8834

Volume:05, Issue:09 "September 2020"

extreme poverty. (World Bank, 2018)

\section{Economic Relations}

In the first quarter of 2020, ASEAN surpassed both the EU and the United States to become China's top trading partner. (ASEAN Briefing, 2020). Two factors affecting this outcome have been the extended lockdown measures in Europe and the effects of the US-China trade war. To offset the impacts of the US-China trade friction, China has been increasingly looking to SouthEast Asian regions to fill the gaps. The Sino-US trade friction is very unlikely to affect ChinaASEAN industrial cooperation. In fact, the US-China trade dispute is likely to act as a catalyst for bilateral relations with the trade war set to drive Chinese investment in ASEAN to \$500 billion dollars by 2030 according to the Asean+3 Macroeconomic Research Office (Lee, 2018). China was also forecasted to account for 22 percent of ASEAN's trade by 2035, with ASEAN accounting for $18 \%$ of China's.

Despite the pandemic and trade tensions, China's economy is expected to remain resilient and have a robust rebound next year in 2021 with forecasted growth of 8.2 percent. (IMF, 2020) This is due to comprehensive policies implemented by the Chinese authorities in reaction to the crisis including a large fiscal stimulus, adequate liquidity, targeted credit to SME's, macro-prudential policies and strict lockdown implementation. South East Asia is also projected to have a growth rebound of 6.2 percent. (IMF, 2020) The regional integration between these two Asian powers is set to increase in the post-pandemic world as a reaction to the rise of protectionist policies in the West and to make their economies resilient to volatility shocks. Integration also has optimistic prospects due to both powers being a part of the Regional Comprehensive Economic Partnership (RCEP) free trade agreement later in 2020. The RCEP is set to become the largest FTA in the world and includes the countries of ASEAN, China, Japan, South Korea, Australia, and New Zealand. This means that in the broader picture, ASEAN+3-ASEAN, China, Japan and South Korea are likely to undergo high levels of regional integration in coming years.

While there is skepticism around the longevity of ASEAN's status as China's largest trading partner, both countries have had more successful epidemic control than many Western countries and the results are likely to depend on a number of uncertain factors like international relations, epidemic control and the potential rise of protectionism. The volatile international environment makes it conducive for these two geographically proximate Asian countries to deepen regional cooperation. Because China's regions are diverse in terms of development, even newly-emerging ASEAN countries are likely to find thriving markets and cooperation opportunities. In May 2019, the ASEAN+3 ministers made the decision to make the Chiang Mai Initiative allow local currency swaps. This comes as a salient measure in regards to China's plans of internationalizing the yuan. But more importantly, it signifies a shift away from overreliance on the US dollar. This 


\section{International Journal of Social Science and Economic Research}

ISSN: 2455-8834

Volume:05, Issue:09 "September 2020"

again was a reaction to the uncertainties threatening East Asia such as that of the US-China trade war and is an attempt to create a regional financial system. On 9th September, 2020, Chinese State Councilor and Foreign Minister Wang Yi said that China was willing to give priority to expand scale of currency swaps between ASEAN and China. With the US dollar on a steep decline and on a track to its worst month since 2011 because of pandemic related shocks, ASEAN countries should question their overreliance on the dollar and should seek to have further regional financial integration(Reuters, 2020). Asia as a whole needs to reduce its dependence on the dollar in order to cushion global shocks such as the coronavirus; the Asian Development Bank president has proposed a currency basket system as an ideal solution. (Nikkei Asian Review, 2020). Similar to the proposed Asian Currency Unit between ASEAN and East Asia, countries should continue to seek alternative regional currency blocks. The worldwide dollar crunch is putting pressure on Southeast Asian debt with Southeast Asian payments set to jump 67\% in 2022 to $\$ 41.9$ billion. (Bloomberg, 2020). With Indonesia and Malaysia being some of the worst hit countries, ASEAN especially needs to be responsive to regional currency swap deals that could reduce dollar dependence.

An area where China-ASEAN economic relations where progress is needed is the cooperation of small and medium-sized enterprises. Because SME managers have low levels of professional expertise and are unable to have foreign trade due to complicated market environment and trade barriers abroad. In the practice of SME cooperation between China and ASEAN, language barriers, lack of information in the international market and lack of foreign trade knowledge are pervasive weaknesses. Most of these enterprises can only avail consulting or outsourcing companies for indirect foreign trade operations. (Liao and Luo, 2020) ASEAN and China should work to establish channels to introduce talents and trade between the SME's in the respective regions. Organizing a delegation to coordinate efforts in spreading information on talent recruitment policies and activities, proving low-interest loans and holding of China-ASEAN talent recruitment fairs, would be extremely beneficial. Having these teams in place to recruit local ASEAN talents proficient in Chinese would also aid the Belt and Road operations greatly. ASEAN countries have copious natural resources and low labor costs which increases investment incentive which make them conducive to the growth and development of SME's through the Belt and Road initiatives.

ASEAN-China economic integration and cooperation is likely to increase in following years and both parties should seek to ensure transparency, seek shared benefits through collaboration and continue to develop an open and inclusive Asian regional architecture.

The South China Sea Issue 


\section{International Journal of Social Science and Economic Research}

ISSN: 2455-8834

Volume:05, Issue:09 "September 2020"

The territorial and maritime contentions in the South China Sea have been a major irritant in China and ASEAN's otherwise flourishing relationship. China claims the 'nine dash line', a vaguely demarcated and extremely large part of the South China Sea which overlaps with the territorial claims of many ASEAN countries. The most recent flashpoints of the issue have been between Vietnam and China where in 2014, China introduced a drilling rig that led to clashing of ships. Military tensions currently run high in the region despite ASEAN's wishes to settle the disputes peacefully.

In the State of Southeast Asia 2020 survey by the ISEAS-Yusof Ishak Institute, 7 of 10 ASEAN members favored China over the United States as an ally. Philippines and Vietnam were the two nations that declared the US as a better ally by overwhelming majority with $83 \%$ and $86 \%$ respectively (Tang, 2020). China has considerable incentive to solve these negotiations because of ASEAN's key significance in its foreign policy; smoothing over these contentions would counter the displayed mistrust some ASEAN nations have of the power and prevent them from strengthening military relations with the USA. However, China's strategic maneuvering in these seas has not stopped and it has called the 2016 tribunal that ruled in favor of the Philippines "ill founded", refusing to be bound by it. The Code of Conduct negotiations has been made more difficult by ASEAN's inability to have a driving consensus on the issue. China benefits greatly from the conflicting views of ASEAN states during these negotiations.

ASEAN needs to take a united lead in these negotiations and prevent individual countries from trying to appease China because of close economic times. In 2012, ASEAN failed to issue a join communiqué on the issue because Cambodia sought to minimize internationalization of the South China Sea issue. As ASEAN Chair of 2020 and one of the most vocal critics of China's actions in the South China Sea, Vietnam could play a key role in enhancing unity and propagating more hardline negotiations. Vietnam has also publicly issued threats of litigation over the issue to China in 2020. Other ASEAN countries could also do the same as it would advance the legality of these nations claims internationally while keeping avenues open to diplomacy. Even as an empty threat, the claim could garner favorable effect on negotiations.

The solving of the South China Sea dispute lies heavily on ASEAN's ability to act as a unified body and apply heavy multilateral pressure on China. ASEAN cannot afford to underestimate itself, China needs stability in the South China Sea if it wants to successfully implement Belt and Road and in its "Two Century Goals" maintaining peaceful and cooperative relations with its neighbors is a prerequisite. China recognizes ASEAN as a valuable strategic and economic partner and trust deficits between the regions undermine the vision of "community of shared destiny" that Xi Jinping touted in 2013. Creating an equitable and comprehensive code of conduct is a key test peacebuilding exercise between the two nations. If ASEAN manages to hold its own against China, it would result in considerable international commendation and prove its relevance in regional and international matters. 
International Journal of Social Science and Economic Research

ISSN: 2455-8834

Volume:05, Issue:09 "September 2020"

ASEAN needs to be at the forefront of negotiations with a united consensus and be more assertive in its negotiations while still avoiding military escalations. There is no simple or facile solution to the South China issue but both countries should continuously work to create an equitable code of conduct to preserve their close-knit relationship in a time of international instability.

\section{Conclusions}

China and ASEAN are linked together by geography, shared interests and decades of economic cooperation. The South China Sea is an important diplomatic issue for the two to solve but it is unlikely that it will shift China's perspective of ASEAN as a key partner. Stabilizing the South China Sea is integral for both bodies to create an environment for close cooperation.

ASEAN should form common consensus on the issue and continue to develop its power as a multilateral body so that it can deal with China more effectively. Both bodies should commit to defining current goals and having transparent dialogue about their shared agendas in regional and international matters. The Belt and Road Initiative provides a new and important framework for the two to deepen cooperation and provides an opportunity for ASEAN to cultivate its voice as a multilateral body. The economic relations and integration of the two countries are likely to continue on a steady path. Increasing market and currency access and facilitating exchange of SME's will help make ASEAN a key player in the global economy. Deepening integration, trade and cooperation between ASEAN and China is an important way to deal with growing uncertainty in global supply chains and trade policies.

\section{Acknowledgments}

I thank Richard Boucher, Senior Fellow at Brown University, Watson Institute for International and Public Affairs, for his direction on the South China Sea section of this paper.

\section{References}

Wang, C. N. (2020). Countries of the Belt and Road Initiative (BRI) - Green Belt and Road Initiative Center. Green BRI. https://green-bri.org/countries-of-the-belt-and-road-initiative-bri

ADB (2017). Meeting Asia’s Infrastructure Needs. (2017). Asian Development Bank, 1. https://doi.org/10.22617/fls168388-2

The Diplomat. (2020, June 4). ASEAN Must Make the Best of Its New Centrality in China's Diplomacy. https://thediplomat.com/2020/06/asean-must-make-the-best-of-its-new-centralityin-chinas-diplomacy 


\section{International Journal of Social Science and Economic Research}

ISSN: 2455-8834

Volume:05, Issue:09 "September 2020"

LSE. (2018). China's Belt and Road Initiative (BRI) and Southeast Asia: A report tracking the risks and rewards of BRI. LSE, 17. https://www.lse.ac.uk/ideas/publications/reports/china-seabri

Jusoh, S. (2018). The Impact of BRI on Trade and Investment in ASEAN. CIMB ASEAN Research Institute - CARI. https://www.cariasean.org/publications/chinas-belt-and-roadinitiative-bri-and-southeast-asia-publication/the-impact-of-bri-on-trade-and-investment-inasean/\#.X1i-QGczbBI

Oertel, J. (2020, September 7). The new China consensus: How Europe is growing wary of Beijing. ECFR.EU.

https://www.ecfr.eu/publications/summary/the_new_china_consensus_how_europe_is_growi ng_wary_of_beijing

Wroughton, L. (2010, April 25). China gains clout in World Bank vote shift. U.S. https://www.reuters.com/article/us-worldbank-idUSTRE63O1RQ20100425

Mahathir: Malaysia Saves Billions in Renegotiated ECRL Deal with China. (2019). BenarNews. https://www.benarnews.org/english/news/malaysian/rail-deal-04152019164237.html

Chang Law. (2019). China \& Singapore Agree to Assemble Multi-National BRI panel. https://changarbitration.com/2019/03/china-singapore-agree-to-assemble-multi-national-brimediation-panel/

World Bank. (2018). Belt and Road Initiative. https://www.worldbank.org/en/topic/regionalintegration/brief/belt-and-road-initiative

ASEAN Briefing. (2020, May 20). ASEAN Overtakes EU to Become China's Top Trading Partner in Q1 2020. ASEAN Business News.

https://www.aseanbriefing.com/news/asean-overtakes-eu-become-chinas-top-trading-partnerq1-2020

Lee, A. (2018, October 25). Trade war will drive Chinese investment in Asean to US\$500 billion by 2035, think tank says. South China Morning Post. https://www.scmp.com/economy/globaleconomy/article/2170205/trade-war-will-drive-chinese-investment-asean-us500-billion

(IMF 2020). Global Economic Prospects. World Bank.

https://www.worldbank.org/en/publication/global-economicprospects\#:\%7E:text=China\%20is\%20expected\%20to\%20slow,to\%205.4\%20percent\%20in\%2 
International Journal of Social Science and Economic Research

ISSN: 2455-8834

Volume:05, Issue:09 "September 2020"

\section{$\underline{02021 .}$}

Reuters. (2020, July 28). King dollar's decline ripples across the globe.

https://www.reuters.com/article/us-health-coronavirus-dollar-analysis-idUSKCN24T1G5

Nikkei Asian Review. (2020, March 4). Asia must rely less on dollar to cushion shocks: ADB chief. https://asia.nikkei.com/Editor-s-Picks/Interview/Asia-must-rely-less-on-dollar-to- cushionshocks-ADB-chief

Bloomberg. (2020). Worldwide Dollar Crunch Raises Red Flags in Asia Debt Market.

https://www.bloomberg.com/news/articles/2020-03-24/worldwide-dollar-crunch-raises-red-

flags-in-asia-s-debt-market

Liao, S., \& Luo, Z. (2020). China-ASEAN SME Cooperation Under the Belt and Road Initiative Obstacles and Path Choices to Deepen Development. International Journal of Business and Economics Research, 9(3), 117. https://doi.org/10.11648/j.ijber.20200903.14

Tang, S. M. (2020). State of Southeast Asia 2020 survey. ISEAS-Yusof Ishak Institute. https://www.iseas.edu.sg/wp-content/uploads/pdfs/TheStateofSEASurveyReport 2020.pdf 